\title{
2018 Fund for Latino Scholarship Recipients
}

$\mathrm{T}$ he Latino Scholarship Fund's primary goal is to encourage and support the recruitment, retention, and promotion of Latina/o political scientists (especially students and tenure track junior faculty); the secondary goal is to support research on Latino politics in the United States (especially students and tenure track junior faculty). Grants for the 2018 cycle were awarded to those individuals, institutions, and projects whose purposes most clearly match the goals of the Fund, and whose proposals most persuasively demonstrate capacity for successful completion. Applications for the Fund close annually each June. Learn more about this year's Fund recipients:

\section{Kristine Kay-Erkiletian}

Kristine is a $\mathrm{PhD}$ candidate in political science at the University of California, Berkeley affiliated with the Institute of Governmental Studies. This year she will also be a BELS Fellow through the Center for the Study of Law \& Society. She studies American

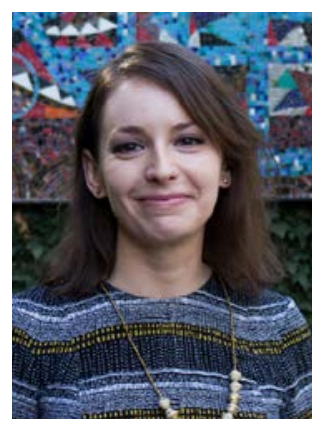
politics with a focus on the political psychology of social groups, including the relationship between in-group identification and emotions. Her work on race and class identification among AfroBrazilians has been published in Politics, Groups and Identities, and her work on coethnic turnout appeared in The Journal of Politics. She has ongoing projects manipulating the strength of identification with racial and ethnic groups. The APSA Fund for Latino Scholarship will help her to investigate the effects of current policy proposals on strength of Latino group identification. She seeks to determine the effects of the citizenship question that is being proposed for the upcoming US Census. Specifically, Kristine will run a survey experiment that investigates the effects of this new question upon Latino/as' racial/ethnic, national and partisan identification. She will also examine the concurrent effect this question may have upon Latino/a's sense of inclusion in American politics.

\section{Brian Lovato}

Brian is a visiting assistant professor at Augustana College with experience in teach-

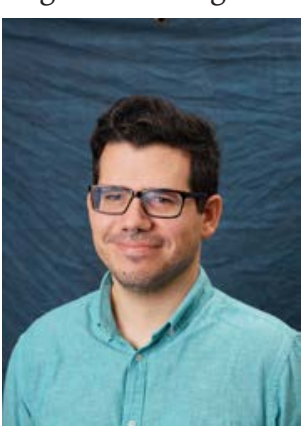

ing, research, and labor organizing. $\mathrm{His}$ research focuses on social movements, identity politics, and critical Marxist theory. His first book, Democracy, Dialectics, and Difference, was released by Routledge in 2016 and argues for a renewal of the Marxist tradition grounded in radical democracy and Hegelian thought. His current research in the area of comparative political theory argues that all liberalism is racial liberalism and that no attempts to salvage its universalist core can successfully generate an anti-racist politics. He turns to the Black Radical Tradition and theorist-practitioners of decolonization in order to propose an alternative. Articles on this and other subjects have been published in or are forthcoming in PS, Rethinking Marxism, The Review Journal of Political Philosophy, and Political Parties, Interest Groups and Organizations that Shaped America: An Encyclopedia and Document Collection. As a founding editor of Abolition: A Journal of Insurgent Politics, he has worked to publish scholarship that bridges the divide between academic and activist scholars. He plans on using the resources provided by the Latino Scholarship Fund to attend the Latino Caucus meetings, panels and events at the 2018 meeting of the American Political Science Association.

\section{Angely Martinez}

Angely is a $\mathrm{PhD}$ candidate in political science at Syracuse University. Her research focuses on unrecognized states and their strategy of sovereignty. She visited her first unrecognized state in 2018(Northern Cyprus) and hopes to visit many more. With the generous support from the Fund for Latino Scholarship, Martinez hopes to conduct interviews with officials from unrecognized states. In addition to her primary research, Martinez is an IPSCON Junior Scholar. This program brings together senior faculty with policy experience and graduate students hoping to have a policy career. At the Moynihan Institute of Global Affairs, she contributes to the Global Blackspots Project, which tracks areas around the world governed by transnational criminal organizations, insurgents, and terrorists. Before coming to Syracuse, Martinez received her BA from the University of Alabama. She double majored in international studies and French, with a concentration in peace and conflict Studies. She hails from San Juan, Puerto Rico and was raised in Miami, Florida.

\section{Yanira Rivas Pineda de Melendez}

Yanira is a $\mathrm{PhD}$ candidate at the University of California,Santa Barbara. Her research focuses on crime, the criminal justice system, and political participation in marginalized Latino communities. Yanira is currently conducting field research for her dissertation titled, "CrimeRidden and Heavily Policed: Political Involvement in two Los

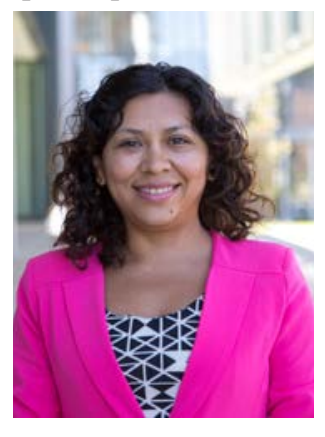
Angeles Public Housing Facilities." Using quantitative and qualitative tools for data collection and analysis, Yanira's dissertation includes a community survey, participant observation, elite interviews, and interviews with community residents. She has been in the field since January 2018 and will utilize the Fund for Latino Scholarship award to finalize all field research by December 2018. Yanira is the recipient of numerous research awards including the UCSB Chicano Studies Institute Research Grant, UCSB Humanities and Social Sciences Research Grant, UCSB Department of Political Science Graduate Research and Training Grant, and the APSA Fund for Latino Scholarship Grant. She has been a Graduate Division Dissertation Fellow, Graduate Opportunity Fellow, SAGE Fellow, and a Sally Casanova Pre-Doctoral Fellow. When Yanira is not in the field, 
she enjoys teaching for the political science departments at UCSB and Santa Monica College and spending time with her undergraduate research assistants discussing her research and political science in general.

\section{Tana Stamper}

Tana is a rising senior at the University of North Carolina at Chapel Hill finishing up a BA in political science with a minor in

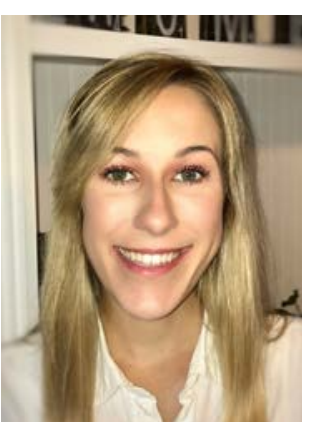
sexuality studies. Tana is also completing a senior honors thesis comparing gender identity and sexual orientation legislation in the post-marital equality state. She is applying to political science $\mathrm{PhD}$ programs this fall and intends to focus on comparative politics. Her research interests revolve around identity, especially concerning the intersection of gender identity, sexual orientation and/or race and ethnicity. Tana has worked as a research assistant for numerous professors in the UNC-Chapel Hill political science department. She also received the Thad L. Beyle Research Award for her work about Latinas in local government. Thanks to the generous APSA Fund for Latino Scholarship, Tana will be able to attend the upcoming 2018 APSA Annual Meeting, where she will present her research paper "Latinas in Local Government: A Case Study of How Electorates Can Hurt or Help" on the Gender, Ethnicity, and Urban Politics panel.

\section{Fernando Tormos-Aponte}

Fernando is a postdoctoral fellow with the Scholars Strategy Network based at the University of Missouri in St. Louis and a

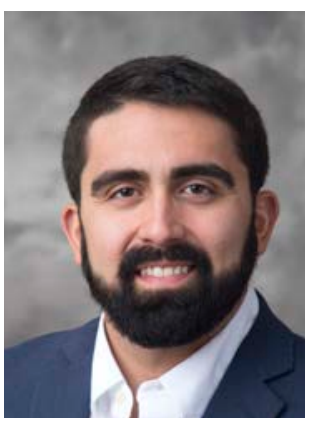
research fellow of the Southern Methodist University Latino Center for Leadership Development. He earned his MA and $\mathrm{PhD}$ in political science from Purdue University, and a BA from the University of Puerto Rico, Río Piedras. Dr. Tormos-Aponte specializes in social movements, identity politics, social policy, and transnational politics.
His research focuses on how social movements overcome internal divisions and gain political influence. Tormos-Aponte's work has appeared in Politics, Groups, and Identities, Environmental Policy and Governance, and in the edited volume The Legacy of Second-Wave Feminism in American Politics. He is currently working on his first book, titled Mobilizing Difference: The Power of Inclusion in Transnational Social Movements. As a Latino Scholarship Fund award recipient he plans to attend the 2018 APSA Annual Meeting, where he will facilitate a business meeting for the Scholars Strategy Network, attend the Latino Caucus workshop, and support the APSA Hackathon.

\section{Rachel Torres}

Rachel (MFP 2017-18) is currently a thirdyear graduate student at the University of Iowa in the political science department,

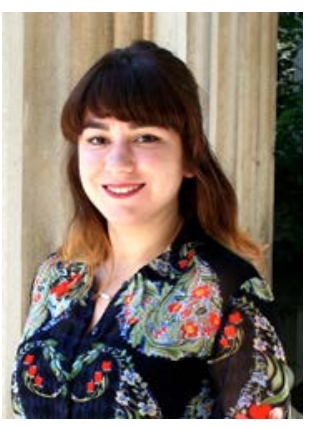
focusing on the study of race and ethnic politics. She graduated from the University of North Texas in 2016 with a BA in political science. Rachel was previously a McNair Scholar and participated in UNT's National Science Foundation sponsored research experience for undergraduates on conflict and peace studies. Rachel has presented her work at the Midwest Political Science Association's 2016 and 2018 annual meetings, as well as the Western Political Science Association's Spring 2018 meeting. The Fund for Latino Scholarship award will allow her to present her work at the 2018 APSA Annual Meeting and to attend the 2018 Latino Politics Workshop.

\section{María Laura Veramendi García}

María is a Peruvian sociologist (PUCP, 2010) and a third year PhD student at Syra-

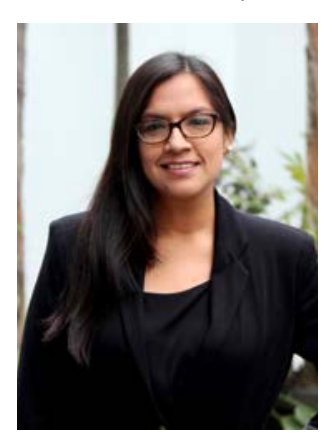
cuse University, studying comparative politics and public policy. She also holds an MPA from the same university (De Sardon-Glass Fellow, 20142015). María Laura's research experience has focused on the evaluation of education policies in urban and rural areas of Peru, the relation between education and citizenship, among others. She has also held executive positions in organizations working towards the promotion of evidencebased policymaking and gender equity in academia. These experiences, along with a brief stage within the Peruvian bureaucracy, triggered María Laura's interest in studying the political obstacles that public policies face on the road to a successful implementation. Driven by such concern, her dissertation will focus on the politics of welfare policies in Latin America from a comparative perspective. In this project, she will pay particular attention to the effects of past policies and political events in later policymaking processes. With support from the Fund for Latino Scholarship, María Laura will attend the 2018 APSA Annual Meeting for the first time. She considers this to be a great opportunity to meet and learn from scholars working on topics that are close to her research interests and to enhance skills and knowledge that are crucial for her next steps. During the meeting, she will also benefit from participating in discussions on topics that are highly relevant for her personal experience, such as the challenges of being a member of the Latino community working in the US academic environment.

\section{Randy Villegas}

Randy is a PhD student in the politics department at the University of California, Santa Cruz, and a Kern County native. Villegas's research interests are rooted in the experiences and communities he

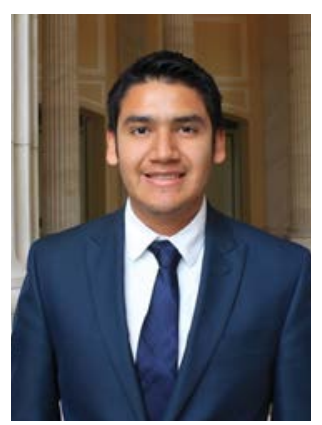
comes from: Latino Politics, Immigration, Civic Engagement, Poverty, and Politics in California's Central Valley. Prior to beginning graduate school Villegas worked as a journalist and an organizer in Bakersfield, CA. He is currently featured in the California State Capitol Museum, in their newest 'Unity' exhibit for his work around social justice issues in Kern County. After completing his $\mathrm{PhD}$, he hopes to return to his community in Kern, or a similar underserved area in the Central Valley to inspire other young schol- 
ars, and make a difference in people's lives. The grant from the APSA Fund for Latino Scholarship will play a vital role in Randy's preliminary data collection for his project Voices from the Valley of Vulnerability which seeks to investigate the relationship between mixed status family households and the civic engagement of second generation children of immigrant parents. This research has the potential to uncover new data on California's future electorate and underlying motivations for civic engagement. It contributes to the Fund for Latino Scholarship mission by further investigating Latino politics in the United States, especially in a context which is more hostile to immigrant families.

\section{Gabriela Vitela}

Gabriela is a $\mathrm{PhD}$ candidate in the political science department at Louisiana State University. Her research interests include American politics, institutions, public policy, and race, gender and ethnicity. Gabriela's dissertation examines how women of color, particularly Latinas, navigate campaign finance. She will address how well Latinas are able to raise money to run for the House of Representatives. She argues that current literature on how women and minorities fund campaigns fails to take into account the particularities of being both a woman and a racial or ethnic minority. Gabriela is a first generation scholar and a Chicana from Texas and enjoys sharing her experiences with her students. She is currently on the job market and with the support of the Fund for

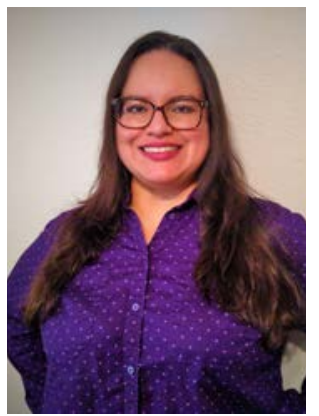
Latino Scholarship will travel to Boston for the 2018 APSA Annual Meeting. There she will attend panels, meetings, and interviews, as well as meet and discuss possible research collaborations. Gabriela's goal is to attain a tenure track position so that she may continue her research, teaching, and mentoring of other Latinas in higher education

\section{Catherine Wineinger}

Catherine is a $\mathrm{PhD}$ candidate in political science at Rutgers University. Her research interests include women's representation, Congress, and political parties.
Her dissertation analyzes the evolving role of Republican congresswomen as party messengers in the House of Representatives. She has also written on the intersection of race, gender, and conservative ideology. During her time in graduate school, Catherine was a research assistant at the Center for American Women and Politics, a seminar fellow at the Institute for Research on Women, and a 2017-2018 Woodrow Wilson Women's Studies fellow. She is the recipient of a Congressional Research

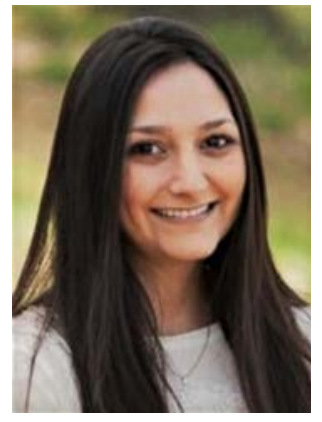

Grant from the Dirksen Congressional Center as well as the 2016 Carrie Chapman Catt Prize for Research on Women and Politics. Prior to Rutgers, she earned her BA at the University of San Diego, where she was a McNair Scholar. With travel support from the Fund for Latino Scholarship, Catherine will be able to present her work at the 2018 APSA Annual Meeting and participate in the 2018 Pre-Conference for Latino Politics Workshop. 